Antarctic Science 28(1), 29-34 (2016) (c) Antarctic Science Ltd 2015. This is an Open Access

article, distributed under the terms of the Creative Commons Attribution-NonCommercial-

ShareAlike licence (http://creativecommons.org/licenses/by-nc-sa/4.0/), which permits

noncommercial re-use, distribution, and reproduction in any medium, provided the same

Creative Commons licence is included and the original work is properly cited. The written

permission of Cambridge University Press must be obtained for commercial re-use.

\title{
Have Antarctic toothfish returned to McMurdo Sound?
}

\author{
STEVEN J. PARKER ${ }^{1}$, SOPHIE MORMEDE ${ }^{2}$, ARTHUR L. DEVRIES $^{3}$, \\ STUART M. HANCHET ${ }^{1}$ and REGINA EISERT ${ }^{4}$ \\ ${ }^{1}$ National Institute of Water and Atmospheric Research, PO Box 893, Nelson 7040, New Zealand \\ ${ }^{2}$ National Institute of Water and Atmospheric Research, Private Bag 14901, Wellington 6021, New Zealand \\ ${ }^{3}$ Department of Animal Biology, University of Illinois, Urbana, IL 61801-3704, USA \\ ${ }^{4}$ Gateway Antarctica, University of Canterbury, Private Bag 4800, Christchurch 8140, New Zealand \\ steve.parker@niwa.co.nz
}

\begin{abstract}
A dramatic reduction in catch rates of Antarctic toothfish in McMurdo Sound, Antarctica, has led to conclusions that the commercial bottom longline fishery for toothfish in the Ross Sea has drastically altered the toothfish population with cascading effects on the McMurdo Sound ecosystem. However, results from a new monitoring programme for Antarctic toothfish and other top predators carried out in McMurdo Sound in 2014 have shown toothfish catch rate, fish size and fish age similar to those observed prior to 2002. These results suggest that either large and old fish have returned to McMurdo Sound following a temporary environmentally driven absence or that they remained locally present but were not detected in the areas sampled. These findings highlight the importance of continued standardized monitoring for detecting the potential effects of fishing on the Ross Sea ecosystem.
\end{abstract}

Received 24 March 2015, accepted 17 August 2015, first published online 28 September 2015

Key words: effects of fishing, longline survey, population decline, Ross Sea

\section{Introduction}

A controversial high seas bottom longline fishery for Antarctic toothfish, Dissostichus mawsoni Norman (Nototheniidae), began in the Ross Sea in 1997 (Hanchet et al. 2010). The stock assessment for Ross Sea toothfish, which indexed the abundance and demographics of the entire Ross Sea region (Fig. 1), indicated a 2013 stock status of $c .75 \%$ of the unfished spawning biomass (Mormede et al. 2014a). Analysis of fishery data suggested that no change in catch per unit effort had occurred for the fishery as a whole, or for fishing in the southern Ross Sea (Hanchet et al. 2010, Mormede et al. 2014b). However, a 40 year record of toothfish catches conducted for the purpose of biological specimen acquisition in McMurdo Sound (Fig. 1) showed a dramatic reduction in the catches of toothfish after 2001, and in 2006, 2007, 2009 and 2011 very few toothfish were collected (Ainley et al. 2013). As these data were the main source of information regarding local toothfish abundance in McMurdo Sound, the results caused concern and were interpreted as indicating that the Ross Sea toothfish fishery had potentially diminished the abundance of large toothfish through range contraction, leaving McMurdo Sound with only juvenile toothfish $(<100 \mathrm{~cm})$ in low abundance (Ainley et al. 2013).

It is important to resolve this discrepancy because Antarctic toothfish appear to be an important component of the diet of predators inhabiting McMurdo Sound and in the wider western Ross Sea (Ainley \& Siniff 2009, Ainley \& Ballard 2012, Eisert et al. 2013, Eisert et al. 2014, Pinkerton $\&$ Bradford-Grieve 2014). Documenting the current status of the toothfish population in McMurdo Sound is therefore essential to ensure it is consistent with the ecosystem approach to fisheries as implemented by the Commission for the Conservation of Antarctic Marine Living Resources (SC-CAMLR 2013, Hanchet et al. 2015).

To address these issues, New Zealand began a monitoring programme, as recommended by Ainley et al. (2013), to monitor toothfish abundance and investigate interactions between Antarctic toothfish, Weddell seals (Leptonychotes weddellii Lesson), and killer whales (Orcinus orca L.) in McMurdo Sound. This study is also a key component of the research and monitoring plan for the proposed marine protected area in the Ross Sea, as agreed by CCAMLR (CCAMLR 2013). In the 2014/15 summer season, we conducted a collaborative pilot survey to determine the appropriate methods, gear configuration and survey locations for a longer term monitoring study by combining the sampling experience and techniques from the McMurdo toothfish sampling programme (DeVries) with fisheries survey techniques. Although only a single pilot season has been conducted, the purpose of this paper is to convey these initial results and their implications for the conclusions on the toothfish population and the effects of fishing on ecosystem dynamics in McMurdo Sound. 


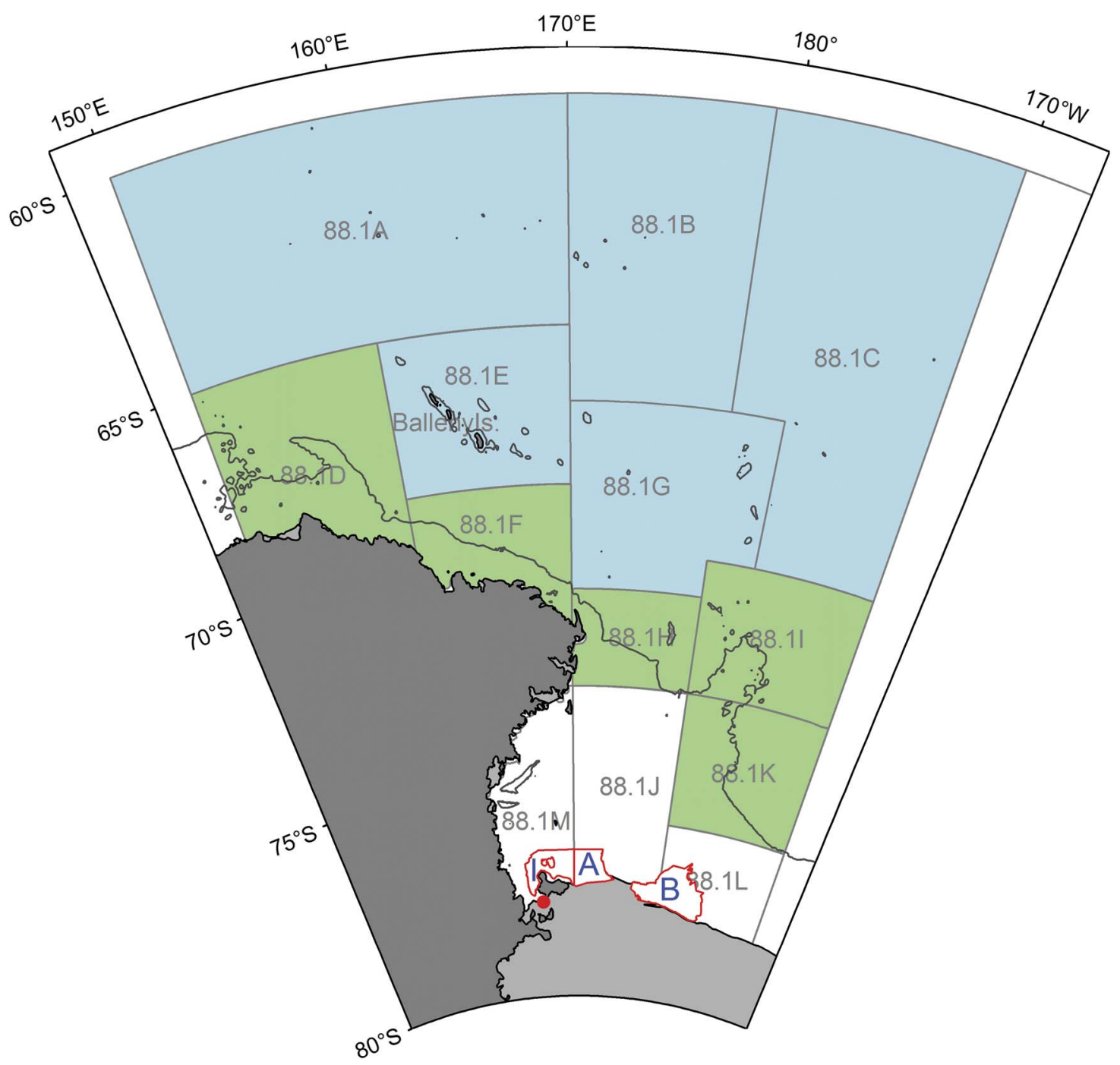

Fig. 1. Small Scale Research Units (SSRUs) in the Ross Sea roughly indicating northern (blue), slope (green) and shelf (white) regions, and three survey strata (A, B and I) from the 2014 Ross Sea shelf vessel-based survey (red lines, see Mormede et al. 2014b). The location of Scott Base, McMurdo Sound, is indicated by a red point. Grey line indicates the $1000 \mathrm{~m}$ depth contour.

\section{Methods}

Fish collection procedures were similar to and used much of the same equipment (DeVries) previously reported by
Ainley et al. (2013). A hole was made through fast ice, typically $2 \mathrm{~m}$ thick, and a heated hut was placed over the hole with a floor access port. An electric winch (Mount Sopris Instrument Company, Denver) holding $1000 \mathrm{~m}$ of

Table I. Details of the 12 sampling events in McMurdo Sound in 2014. Gear code refers to the specific gear configuration used as detailed in Table II.

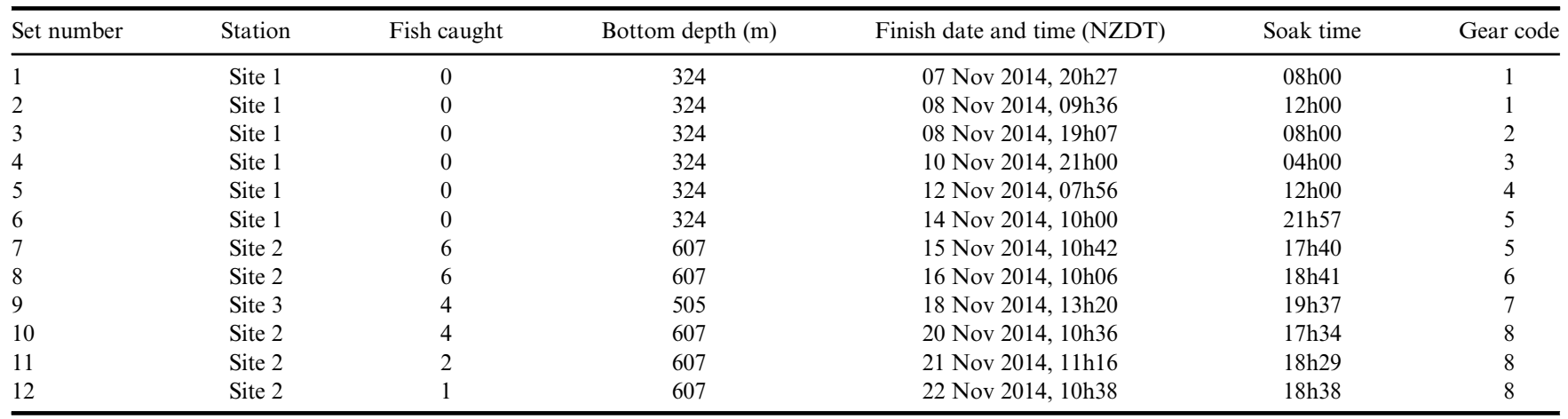


Table II. Sampling gear configurations trialled in McMurdo Sound in 2014 .

\begin{tabular}{ll}
\hline Code & Configuration \\
\hline 1 & $\begin{array}{l}35 \text { hooks spaced at } 1.4 \mathrm{~m} \text { on integrated weight line, vertical } \\
35 \text { hooks spaced at } 1.4 \mathrm{~m} \text { on integrated weight line with drogue, } \\
\text { horizontal }\end{array}$ \\
3 & $\begin{array}{l}18 \text { hooks spaced at } 3-4 \mathrm{~m} \text { with floats attached to polypropylene } \\
\text { line, horizontal }\end{array}$ \\
& $\begin{array}{l}\text { 6 hooks on cable clamps spaced at } 1.4 \mathrm{~m} \text { on wire snoods } \\
\text { clamped on vertical wire }\end{array}$ \\
5 & $\begin{array}{l}28 \text { hooks on line clips spaced at } 1.4 \mathrm{~m} \text { on vertical wire but } \\
\text { hooks } 15-19 \text { at } 3 \mathrm{~m} \text { interval }\end{array}$ \\
6 & $\begin{array}{l}\text { Same as } 5 \text { but lowest hook removed to avoid amphipods } \\
10 \text { hooks on line clips spaced at } 1.4 \mathrm{~m} \text { on vertical wire }\end{array}$ \\
8 & $\begin{array}{l}20 \text { hooks spaced at } 1.4 \mathrm{~m} \text { on vertical integrated weight line, } \\
\text { omitting lowest hook }\end{array}$ \\
\hline
\end{tabular}

$2.4 \mathrm{~mm}$ stainless steel wire was used to lower a $20 \mathrm{~kg}$ weight to the sea floor.

Several configurations of the sampling gear were trialled to develop a standardized method for future surveys so that the gear could be deployed through a hole in the ice on a vertical line from a winch. Above the weight, 15-0 "J" hooks (Mustad) were attached to the main wire every $1.4 \mathrm{~m}$ on $300 \mathrm{~mm}$ snoods $(250 \mathrm{~kg}$ twisted nylon tied to line clips) and kept from sliding with copper crimps placed $100 \mathrm{~mm}$ apart. The actual configuration and the number of hooks used, as well as the composition of the line near the bottom, varied for the first few sets as the most feasible method was refined (detailed in Tables I and II). Hooks were baited with $c$. $200 \mathrm{~g}$ of squid (Nototodarus sloanii Gray, as one-third of a squid), and lines were set at various times of day (and tide) with a target soak time of $12 \mathrm{~h}$, although this was also varied (Table I).

Water depth was verified using a calibrated Simrad $38 \mathrm{kHz}$ EK-60 acoustic echosounder, and the winch wire deployed was typically within a few metres of this value (slightly longer due to currents and using a wire counter on the winch). Bottom could be manually detected via slack wire when the weight reached the bottom.

Sample locations were chosen based on records of previous sampling effort (Ainley et al. 2013, DeVries) or based on a digital elevation model (Davey 2004). Three sites were chosen; two sites were within $1.5 \mathrm{~km}$ of former collection sites and one site was in deeper water but still within the cluster of former collection sites

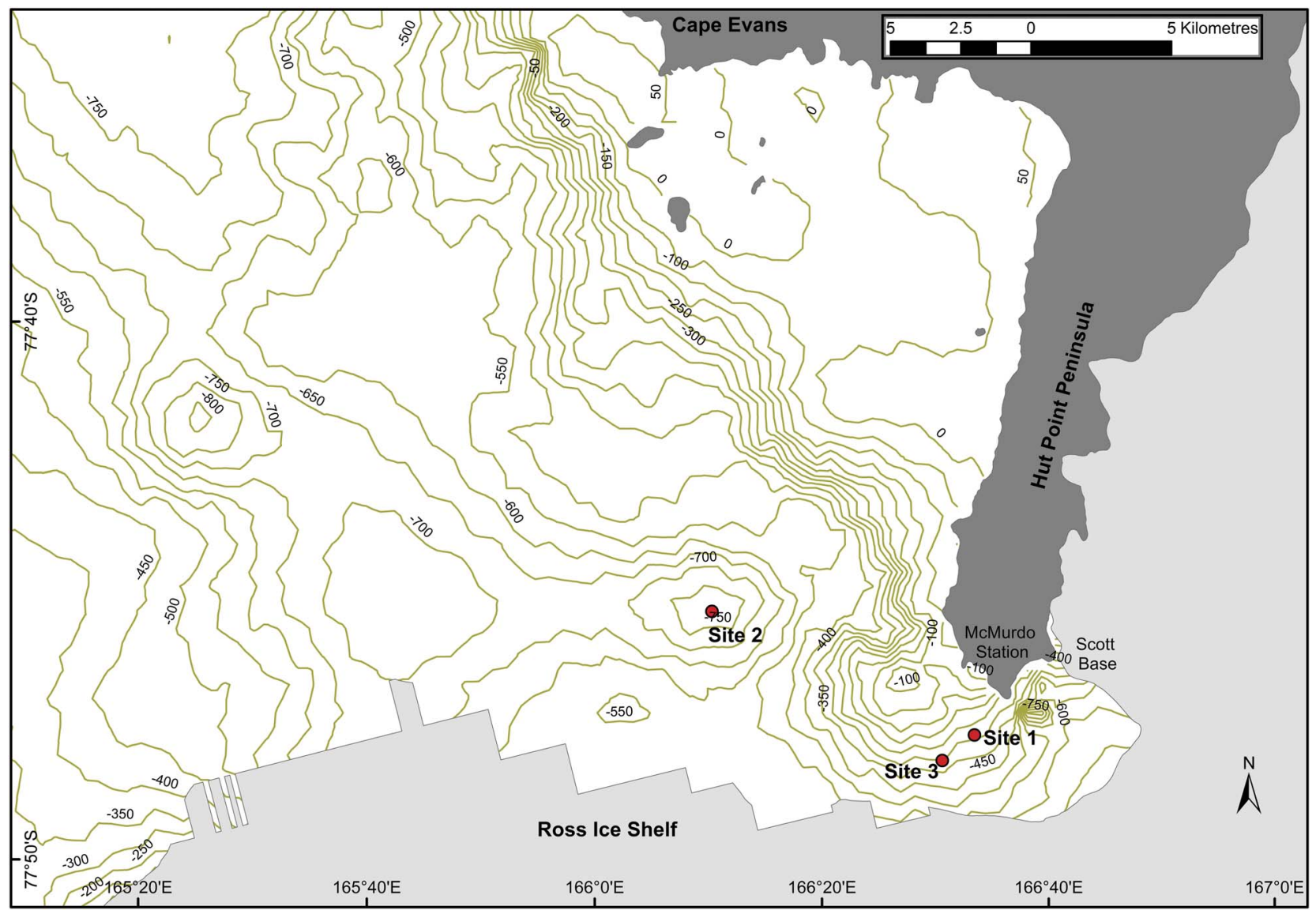

Fig. 2. Bathymetric map of McMurdo Sound based on a digital elevation model (Davey 2004). Points indicate locations sampled in 2014. Scott Base is referenced in Fig. 1. Note that the digital elevation model is coarse and shows indicative depths only. Measured depths for Sites 1-3 were $324 \mathrm{~m}, 607 \mathrm{~m}$ and $505 \mathrm{~m}$, respectively. 
Table III. Details of individual Antarctic toothfish (Dissostichus mawsoni) sampled in McMurdo Sound in 2014. NA indicates not available as fish were tagged and released. Fish ID refers to the set number followed by the hook number (from shallowest to deepest) on which the fish was caught. Hook height indicates the distance of the hook from the bottom.

\begin{tabular}{|c|c|c|c|c|c|c|}
\hline $\begin{array}{l}\text { Fish } \\
\text { ID }\end{array}$ & $\begin{array}{l}\text { Hook height } \\
\text { (m) }\end{array}$ & $\begin{array}{l}\text { Length } \\
(\mathrm{cm})\end{array}$ & $\begin{array}{l}\text { Weight } \\
(\mathrm{kg})\end{array}$ & Sex & $\begin{array}{l}\text { Gonad weight } \\
\text { (g) }\end{array}$ & Age \\
\hline $7-6$ & 32.2 & 140 & 30.6 & F & 192 & 24 \\
\hline $7-24$ & 7.0 & 155 & 39.1 & $\mathrm{~F}$ & 350 & 26 \\
\hline $7-25$ & 5.6 & 142 & 33.3 & F & 426 & 30 \\
\hline $7-26$ & 4.2 & 136 & 30.4 & $\mathrm{~F}$ & 229 & 24 \\
\hline $7-27$ & 2.8 & 123 & 26.8 & F & 177 & 20 \\
\hline $7-28$ & 1.4 & 144 & 39.7 & $\mathrm{~F}$ & 262 & 22 \\
\hline $8-4$ & 36.6 & 124 & 22.4 & $\mathrm{M}$ & 58 & 27 \\
\hline $8-7$ & 32.4 & 138 & 36.7 & F & 163 & 20 \\
\hline $8-12$ & 25.4 & 139 & 26.8 & M & 127 & 26 \\
\hline $8-14$ & 22.6 & 154 & 49.0 & F & 689 & 25 \\
\hline $8-21$ & 12.8 & 108 & 15.6 & $\mathrm{~F}$ & 86 & 14 \\
\hline $8-22$ & 11.4 & 134 & 27.7 & F & 155 & 19 \\
\hline $9-6$ & 7.0 & 138 & NA & NA & NA & NA \\
\hline $9-8$ & 4.2 & 138 & NA & NA & NA & NA \\
\hline $9-9$ & 2.8 & 113 & NA & NA & NA & NA \\
\hline $9-10$ & 1.4 & 125 & 23.1 & $\mathrm{~F}$ & 254 & 28 \\
\hline $10-3$ & 26.8 & 129 & 26.5 & NA & NA & NA \\
\hline $10-8$ & 19.8 & 143 & 35.0 & NA & NA & NA \\
\hline $10-10$ & 17.0 & 133 & 28.8 & NA & NA & NA \\
\hline $10-17$ & 7.2 & 130 & 24.7 & NA & NA & NA \\
\hline $11-7$ & 21.2 & 145 & 36.9 & NA & NA & NA \\
\hline $11-12$ & 14.2 & 149 & 42.1 & NA & NA & NA \\
\hline $12-19$ & 4.4 & 130 & 28.9 & NA & NA & NA \\
\hline
\end{tabular}

(see Ainley et al. 2013). The first site was situated in relatively shallow water $(324 \mathrm{~m})$, so that gear could be tested while close to Scott Base and was not a target sampling site (Fig. 2). This site was within $1 \mathrm{~km}$ of several former collection sites but was shallower than depths reported for those sites (415-495 m estimated from winch wire deployed; Ainley et al. 2013, DeVries et al. 2008). The second site was in a bathymetric depression of $607 \mathrm{~m}$ in the middle of McMurdo Sound, chosen based on the digital elevation model and the depth distribution of toothfish from the Ross Sea commercial catches (550-1800 m, Hanchet et al. 2010).
The third site was a former collection site from 2000 (DeVries et al. 2008). Depth was $505 \mathrm{~m}$ and it was located $1.4 \mathrm{~km}$ from Site 1 (Fig. 2).

When fish were brought to the surface, they were either immediately euthanized and retained for biological samples, or total length was recorded, the fish were tagged with two pink T-bar tags (Hallmark, AU) using CCAMLR tagging procedures (SC-CAMLR 2012) and released. Hook status at hauling (baited, empty, fish) and any invertebrate catch was also recorded.

For fish retained for biological purposes, data and tissue samples were collected for physiological experiments, including ovarian weight and tissue for histology, liver and muscle tissue for stable isotope studies, muscle tissue for genetic studies, stomach contents for diet, blood plasma for steroid profiles, and otoliths for age determination. Ages were determined for retained fish by otolith analysis according to Sutton et al. (2012). Following processing for the above tissue samples, the entire fish was frozen for tissue composition analysis.

\section{Results}

During the period 6-20 November 2014, a total of 12 gear deployments were made at the three sites (Table I). No fish were caught at Site 1. However, a Weddell seal did cache one toothfish carcass in the ice hole and was recorded by video bringing another live toothfish to the hole.

At Site 2, toothfish were caught on every deployment, totalling 19 fish over five sets. Twelve fish were kept for biological samples and seven were tagged and released. The toothfish were typically caught on the hooks closest to the bottom; however, some fish were caught on hooks suspended up to $35 \mathrm{~m}$ off the bottom. Fish apparently interacted with hooks still further off the bottom as snoods holding hooks without bait were often observed twisted around the main line up to $43 \mathrm{~m}$ off the bottom.

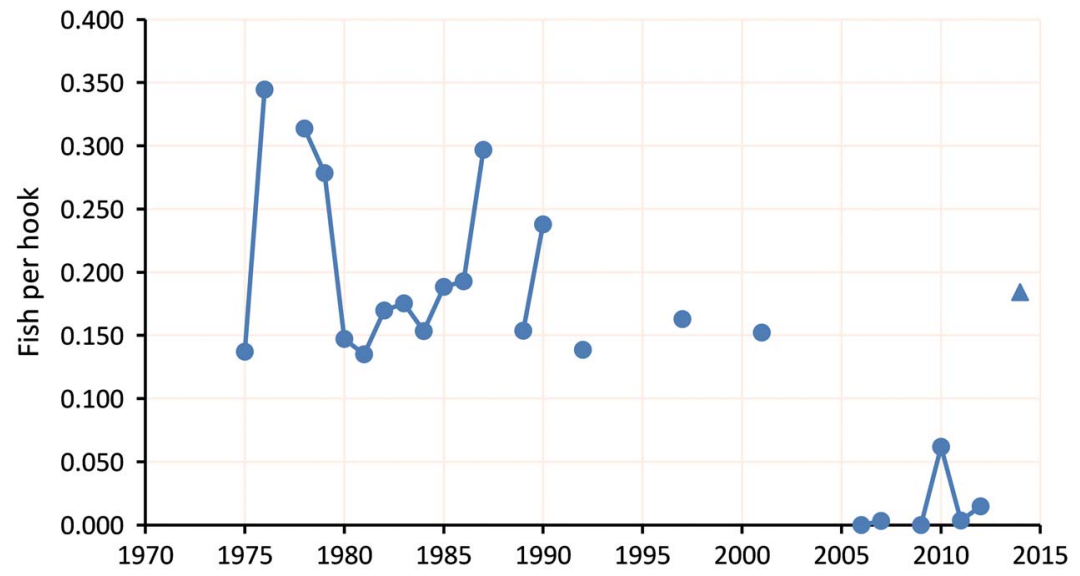

Fig. 3. Catch rates (fish per hook) for toothfish sampled in McMurdo Sound, Antarctica, 1975-2014. Circles indicate pre-2013 data recalculated from Ainley et al. (2013) and the triangle indicates the 2014 value from this study. 
At Site 3, no hut was available to protect electronics, so sampling was done through an unsheltered hole drilled through the ice. Four fish were caught on a single set of ten hooks, three were measured, tagged and released, and one fish was moribund due to amphipod predation was retained for biological samples.

Sites 2 and 3 comprised six sets, and fish were caught on every set ( 23 fish on 125 hooks $=0.184$ fish per hook). The fish were large $($ median $=138 \mathrm{~cm}, 30 \mathrm{~kg})$, relatively old (median $=24$ years), mostly female $(85 \%)$, and all with gonads in a resting developmental stage (Table III). The stomachs of sampled fish were mostly empty, containing only traces of euphausiid or digested fish. Two stomachs contained one or two small Pleuragramma antarcticum Boulenger.

\section{Discussion}

The results from the 2014 research presented here are very similar to data available from before 2002. Comparing our results to data provided by Ainley et al. (2013), the catch rate achieved in 2014 was 0.184 fish per hook, higher than the median of the rates reported for the period from 1975 to 2001 (0.170, Fig. 3). The distributions of fish size and weight were consistent with the historical distributions reported by DeVries et al. (2008) and Ainley et al. (2013), although the proportion of females in our limited sample was higher than the $75 \%$ females reported by Eastman \& DeVries (2000). The age distribution and lengths-at-age were also consistent with the results of Horn et al. (2003), in that the toothfish from McMurdo Sound tended to be shorter at age compared with those sampled further north on the continental slope and northern seamounts (see Fig. 1).

The sampling in 2014 occurred within the cluster of previously sampled sites reported by Ainley et al. (2013) and one site (showing a high catch rate) was at a former collection site. Prior to 2000 , sampling sites were mainly from a single hole at $c .500 \mathrm{~m}$ depth with some trials in deeper or shallower water (Raymond 1975, Eastman \& DeVries 1985, 2000). From 2000 to 2012, sites were typically shallower (415-495 m), which in itself may have influenced toothfish catch rates (DeVries et al. 2008, Ainley et al. 2013). Although the sampling described here was a pilot survey, the results clearly demonstrated that i) toothfish were not absent or at very low catch rates in McMurdo Sound in November 2014, ii) the sizes of the fish sampled were similar to those observed in McMurdo Sound prior to 2002, and iii) the fish were old (median age 24 years), indicating that the toothfish present were not young fish just recruiting to McMurdo Sound.

The results from the 2014 ice-based work also match well with the size and age composition of toothfish sampled in outer McMurdo Sound during a vessel-based standardized bottom longline survey conducted in
January 2014, where the closest surveyed area (west of Cape Evans) was only $30 \mathrm{~km}$ away from the sea ice sample sites (Mormede et al. 2014b, see survey strata in Figs 1 and 2). Vessel-based survey data showed relatively high catch rates near Cape Evans, and a higher proportion of large fish $(120-160 \mathrm{~cm})$ in/near McMurdo Sound compared with other areas of the Ross Sea shelf surveyed. However, the fish in the present study tended to be even older than the mode of large fish sampled in the survey (16-18 years in Mormede et al. 2014b).

The root cause for the decline in toothfish catches from 2003-12 in McMurdo Sound remains puzzling. Several possible causes have been considered (Hanchet et al. 2010, SC-CAMLR 2012). These included the effects of two large grounded icebergs that changed the oceanography, productivity and seasonal ice dynamics in McMurdo Sound in the early 2000s (Robinson \& Williams 2012). Other factors that may have contributed to the decline in observed numbers of toothfish include changes in abundance, the proximity of sampling sites to ice cracks providing access for predatory Weddell seals, or the use of sampling locations that were too shallow (SC-CAMLR 2012). Antarctic toothfish size and catch rates show a strong relationship with depth, with larger fish in deeper water and the highest catch rates typically in waters $1000-1600 \mathrm{~m}$ in depth, although large fish can be observed in shallow waters (Hanchet et al. 2010, Hanchet et al. 2012). Additional work to standardize historic catch rates for the effect of sampling depth and work to characterize the effects of seasonal ice dynamics on toothfish distribution and abundance are high priorities, as understanding these factors will aid in interpreting both past and future changes in observed toothfish abundance.

It is clear that catch rates and catch characteristics of toothfish in McMurdo Sound in 2014 were similar to observations before 2002. The remarkable change in the observed numbers of fish from 2003-12 could have been a temporary phenomenon (e.g. due to ice dynamics or other environmental effect), or the result of unstandardized changes in sampling effort (e.g. changes in depth). Monitoring the abundance and demographics of toothfish requires a spatially stratified survey approach using standardized sampling gear (Hanchet et al. 2010), and will be a critical component in efforts to understand the dynamics of toothfish, their predators and their prey in McMurdo Sound.

\section{Acknowledgements}

This project was funded by the New Zealand Ministry for Primary Industries (MPI) through the University of Canterbury in contract ANT2014-02. We gratefully acknowledge the complex logistical support from Antarctica New Zealand and the US Antarctic Program 
to enable field work on the sea ice. The Ministry of Foreign Affairs and Trade and MPI provided technical and permitting support (AMLR permit AMLR14/R04/ Eisert/K070, 4 September 2014), and the project was developed through discussions within the Antarctic working group of the MPI. We thank the reviewers for their thoughtful and constructive comments which improved the manuscript.

\section{Author contribution}

The authors were all involved in the original concept and design of the paper and have been involved in its subsequent drafting and revision.

\section{References}

Ainley, D.G. \& Ballard, G. 2012. Trophic interactions and population trends of killer whales (Orcinus orca) in the southern Ross Sea. Aquatic Mammals, 38, 153-160.

Ainley, D.G. \& SinifF, D.B. 2009. The importance of Antarctic toothfish as prey of Weddell seals in the Ross Sea. Antarctic Science, 21, 317-327.

Ainley, D.G., Nur, N., Eastman, J.T., Ballard, G., Parkinson, C.L., Evans, C.W. \& DeVries, A.L. 2013. Decadal trends in abundance, size and condition of Antarctic toothfish in McMurdo Sound, Antarctica, 1972-2011. Fish and Fisheries, 14, 343-363.

CCAMLR 2013. A draft plan for research and monitoring in the Ross Sea region, in association with spatial marine protection. Delegations of New Zealand and the USA. Document SC-CAMLR-IM-I.BG.03 Rev. 1. Hobart, TAS: CCAMLR.

Davey, F.J. 2004. Ross Sea Bathymetry, 1:2 000 000, Version 1.0, Institute of Geological and Nuclear Sciences Geophysical Map 16. Lower Hutt, New Zealand: Institute of Geological and Nuclear Sciences.

DeVries, A.L., Ainley, D.G. \& Ballard, G. 2008. Decline of the Antarctic toothfish and its predators in McMurdo Sound and the southern Ross Sea and recommendations for restoration. Document SC-CAMLR-WG-EMM-08/21. Hobart, TAS: CCAMLR.

Eastman, J.T. \& DeVries, A.L. 1985. Adaptations for cryopelagic life in the Antarctic notothenioid fish Pagothenia borchgrevinki. Polar Biology, 4, 45-52.

Eastman, J.T. \& DeVries, A.L. 2000. Aspects of body size and gonadal histology in the Antarctic toothfish, Dissostichus mawsoni, from McMurdo Sound, Antarctica. Polar Biology, 23, 189-195.
Eisert, R., Pinkerton, M.H., Newsome, S.D. \& Oftedal, O.T. 2013. A critical re-examination of the evidence for a possible dependence of Weddell Seals (Leptonychotes weddellii) on Antarctic toothfish (Dissostichus mawsoni) in the Ross Sea, Antarctica. Document SC-CAMLR-WG-EMM-13/28. Hobart, TAS: CCAMLR.

Eisert, R., Pinkerton, M.H., Torres, L., Currey, R.J.C., Ensor, P.H., Ovsyanikova, E.N., Visser, I.N. \& Oftedal, O.T. 2014. Update on the Top Predator Alliance project, 2013-14 season: killer whales. Document SC-CAMLR-WG-EMM-14/52. Hobart, TAS: CCAMLR.

Hanchet, S.M., Mormede, S. \& Dunn, A. 2010. Distribution and relative abundance of Antarctic toothfish (Dissostichus mawsoni) on the Ross Sea shelf. CCAMLR Science, 17, 33-51.

Hanchet, S.M., Mormede, S., Parker, S.J., Dunn, A. \& Jo, H.-S. 2012. Results of a CCAMLR-sponsored research survey to monitor abundance of pre-recruit Antarctic toothfish in the southern Ross Sea, February 2012. Document SC-CAMLR-WG-FSA-12/41. Hobart, TAS: CCAMLR.

Hanchet, S., Sainsbury, K., Butterworth, D., Darby, C., Bizikova, V., Godøa, O.R., Ichila, T., Kocka, K.H., López Abellána, L. \& VACCHI, M. 2015. CCAMLR's precautionary approach to management focusing on Ross Sea toothfish fishery. Antarctic Science, 27, 10 1017/S095410201400087X.

Horn, P.L., Sutton, C.P. \& DeVries, A.L. 2003. Evidence to support the annual formation of growth zones in otoliths of Antarctic toothfish (Dissostichus mawsoni). CCAMLR Science, 10, 125-138.

Mormede, S., Dunn, A. \& Hanchet, S.M. 2014a. A stock assessment model of Antarctic toothfish (Dissostichus mawsoni) in the Ross Sea region incorporating multi-year mark-recapture data. CCAMLR Science, 21, 39-62.

Mormede, S., Parker, S.J., Hanchet, S.M., Dunn, A. \& Gregory, S. 2014b. Results of the third CCAMLR sponsored research survey to monitor abundance of sub-adult Antarctic toothfish in the southern Ross Sea, February 2014 and development of the time series. Document SC-CAMLR-WG-FSA-14/51. Hobart, TAS: CCAMLR.

Pinkerton, M.H. \& Bradford-Grieve, J.M. 2014. Characterising foodweb structure to identify potential ecosystem effects of fishing in the Ross Sea, Antarctica. ICES Journal of Marine Science, 71, 10.1093/icesjms/fst230.

RAYMOND, J.A. 1975. Fishing for Antarctica's largest fish, the Antarctic cod. Marine Technology Society Journal, 9, 32-35.

Robinson, N.J. \& Williams, M.J.M. 2012. Iceberg-induced changes to polynya operation and regional oceanography in the southern Ross Sea, Antarctica, from in situ observations. Antarctic Science, 24, 514-526.

SC-CAMLR. 2012. Report of the Thirty-First Meeting of the Scientific Committee (SC-CAMLR-XXXI). Hobart, TAS: CCAMLR, $106 \mathrm{pp}$.

SC-CAMLR. 2013. Report of the Thirty-Second Meeting of the Scientific Committee (SC-CAMLR-XXXII). Hobart, TAS: CCAMLR, $122 \mathrm{pp}$.

Sutton, C.P., Parker, S.J. \& Horn, P.L. 2012. Manual for age determination of Antarctic toothfish (Dissostichus mawsoni): V2. Document SC-CAMLR-WG-FSA-12/43. Hobart, TAS: CCAMLR. 